\title{
Why Arab Societies do not Encourage the Work of Their Members in Hotels?
}

\author{
Qusay Q. Khaleefah ${ }^{1}$, Omar A. Jawabreh ${ }^{2}$, Bashar M. Al Najdawi ${ }^{3} \&$ Rami Muneer Mahmoud ${ }^{4}$ \\ ${ }^{1}$ Al Balqa Applied University, Aqaba Branch, Aqaba, Jordan \\ ${ }^{2}$ Department of Hotel Management, Faculty of Tourism and Hotel Management, The University of Jordan, \\ Jordan \\ ${ }^{3}$ Al Balqa Applied University, Aqaba Branch, Aqaba, Jordan \\ ${ }^{4}$ Department of Hotel Management, Faculty of Tourism and Hotel Management, The University of Jordan, \\ Jordan \\ Correspondence: Qusay Q. Khaleefah, Al Balqa Applied University, Aqaba Branch, Aqaba, Jordan. E-mail: \\ qusay.khaleefah@gmail.com,o.jawabreh@ju.edu.jo,r.mahmoud@ju.edu.jo,basharnajdawi@gmail.com
}

Received: March 25, 2018

Accepted: September 20, 2018

Online Published: October 25, 2018

doi:10.5539/mas.v12n11p259

URL: https://doi.org/10.5539/mas.v12n11p259

\begin{abstract}
Purpose - This paper aims to determine the readiness of the local community in Aqaba to engage in hotel work. The study problem can be posed by the following question:

Is there an impact of the local Aqaba community on the decision of its employees to work in the hotel field?

Study Importance - The importance and purpose of the study is to benefit from its results to determine the outlook of the members of Aqaba community towards working in the hotel, addressing the negative aspects that may be included in such view. Aiming at spreading national awareness in the minds of citizens corresponding to the social responsibility for the importance of working in this industry on economic, social and cultural bases, whether on the short or long term, and to stand on the extent, to which the Aqaba society accepts the work of its members in the hotel industry.

Design / methodology / approach -The study consists of two aspects, the theoretical aspect, which relies on the Arabic and foreign literature and studies on the concepts and explanations of the variables of this study, namely the decision to work in hotels and the factors influencing it, represented by the influence of customs and traditions of the country, religion, gender, group reference (family) as well as local awareness to work in hotels. Moreover, an analytical practical case study was based on a questionnaire, the study coverage sample population of local population of Aqaba city community, and it can be allows for a broad generalization of the study results for most Arabic communities in the world.

Findings- The results of the study showed that the local community's view of the city of Aqaba does not encourage work in the hotels significantly, and that there is lack of cultural awareness in the local community regarding hotels and areas of work, especially the areas in which women can work. Families in Aqaba also refuse work of their members, especially females in hotels, for fear of sexual harassment by guests on the one hand, and their employees to a lesser extent. Finally this study delivered a clear analysis for the local community readiness to engage in hotel work.
\end{abstract}

Study limitations / implications - The study difficulties were theoretical, due to the lack of previous studies on this subject. There were additional difficulties in this field, where the researcher encountered difficulties during the distribution of the questionnaire, as many individuals refused to fill out the form because of their lack of interest in the subject and did not take it seriously. It is possible, in the future, to adopt a study that will be appointed to one sample only, such as employees of government institutions, private industrial industry, private commercial industry, and military society and military forces, by means of electronically filled questionnaire on the Internet.

Originality / value- This study revealed the most important reasons that lead the youth of Aqaba city and most Arabic communities in the world of to refrain from working in the hotel industry, especially females, and that it 
is possible to raise the awareness of Aqaba society to encourage their members to work in the hotel industry and overcome all the challenges, revealed by the results of the study. Researcher also handled women's work in the hotel industry through the preparation of a hotel project that overcomes all the obstacles and challenges, which were revealed in the results of the study that would prevent the work of women in the hotel industry. In other words, this study, through its results, created the first step towards changing the view of Aqaba society concerning the work of its members in the hotel industry.

Keywords: Jordan, Aqaba local community, customs and traditions, religion, gender, cultural awareness, family's impact, hotel industry

\section{Introduction}

Tourism and hotel industry are important economic, social and cultural resources for the people. Their role is to support the country through access to hard currency, job creation, unemployment reduction, transportation, infraand superstructure, as well as economic support for the rest the industry. Jordan has many touristic attractions that have made it a place on the world tourists' map, especially after Petra became one of the seven new wonders of the world. Tourism greatly affects the local community, helps in exchanging cultures between different peoples and countries, experiencing different customs and traditions of different peoples, as well as increasing tourism awareness among citizens and reducing problems that result from poverty, unemployment and lack of employment opportunities (Shryock, 2004; Shannak \& Obeidat, 2012; Jawabreh et al, 2015). The hotels industry in Jordan has witnessed a qualitative and quantitative increase in the last 20 years. There are hotels in different categories in the majority of the Kingdom's cities, especially in places of touristic attraction, offering a variety of services to suit all categories of tourists. This great renaissance has led to many job opportunities at various levels of hotel work, thus emerged the need for many skilled and qualified workers, who are able to provide services as required by the guests. Therefore, a serious study of the views and outlooks of local community towards hotel work became necessary to support actions, which aim at raising awareness among the citizens regarding the promotion of hotel industry as well as the importance of this industry from the economic, social and cultural aspects (Shunnaq et al., 2008; Amyan et al., 2011, Alananzeh et al., 2018). However high the material and financial potentials of governmental and tourism industry s may be, to develop plans promoting the hotel industry, local community is a key supporter in its success. Therefore, it is necessary to take into account the involvement of the local community in the tourism process clearly, while exerting the required care for the social structure of citizens within any touristic destination, as well as the preservation of cultural identity, customs and traditions of the community, all of which would enhance the tourism process (Mansfeld, 1992).

Jordan is one of the leading tourism countries in the Middle East and one of the fastest growing countries. This is due to Jordan's tourism attractions that attract tourists from all over the world, from a unique geographic location in the heart of the Arab world, and from a variety of natural mountain ranges, valleys, Rivers and desert, climate diversity, and the existence of historic, archaeological and urban components that bear witness to the many civilizations and nations that followed it, such as the Ammonites, the Masons, the Edomites, the Assyrians, the Babylonians, the Persians, the Greeks, and the Nabateans. In addition to the natural elements, the factor of security and stability, integrated tourism services and facilities, social factors and the nature of the friendly and hospitable Jordanian society (Al-Hasanat \& Hyasat, 2011; Al-Shawagfih et al., 2015; Masa'deh, 2016; Jawabreh, 2017a). As a result, the tourism and hotel industry in Jordan has been taken care of by many investments in this industry. Many hotels, restaurants, and travel and tourism offices have been established, especially for international chains such as Sheraton, Mövenpick, and InterContinental. The number of hotels in Jordan, according to Ministry of Tourism and Antiquities, amount to 510 hotels spread in most cities of the Kingdom. This size of investment requires large numbers of workers and different disciplines and expertise. The geographic distribution of hotels in Jordan is concentrated in four geographic regions: Amman, Petra, Dead Sea and Aqaba.

\section{Literature Review}

Taylor (2011) study focused on the creation of social capital through implementing public relations theory and practices in correspondence that serves the interests of society. The results of the study revealed the role of different relationships between international NGOs, local NGOs, business organizations and activists in Jordan, as an example of how social capital is created, when public relations specialists act in ways that enhance local governance and make their society a better place to live in. The study showed the importance of local community and its role in providing human resources to business industry s, through their awareness of business industry s' importance as well as employment opportunities that they provide, so that they create fair balance guiding the society to review the specializations that are deficient in their local human resources. Shryock (2004) focused on 
the hospitality of Jordan and local community, as well as its friendly society that loves guests and provides them with all the services, which guarantee happiness and reassurance during their stay in Jordan. The Jordanian society welcomes its guests from the moment they step foot any city in Jordan. And it tries to make the guest feel like a Jordanian citizen and that they are not strange from their second country (Jordan), where this generosity is also found in remote villages of Jordan and not only in the capital Amman. Jordanian society is trying from the first moment to break the ice in dealing with tourists, remove typicality and social barriers and respectful interaction with the guest, and this is evidence of the tourism awareness of the Jordanian community towards tourists and guests.

It is worth mentioning that this study is evidence of the maturity of thought and awareness of members of Jordanian society, concerning the role of tourism, being a industry that supports the country financially, socially and from media aspect. The tourism industry is the ambassador that creates close international relations with other Arab and foreign countries. Creating loyalty, as well, of members of society, who work and develop this industry. Mansfeld (1992) pointed at the impact of the social perception of local community towards tourism development and the latter's reflection on the positive benefit and the effective value, on society and its members, in the city of Eilat through three related variables (social factors and their impact on the loyalty of workers in the tourism industry towards development) on touristic, economic and social levels, in addition to its role in creating positive attitudes towards tourism development, the perceptions of local population regarding the social effects of tourism development and the extent of this perception, when linked to the economic returns of the population, as a result for tourism development. The results of the study showed that the workers in the tourism industry have greater affiliation than those working in other industry s. The study showed that there is disparity in the perceptions of the local population and a difference in the views regarding impact of tourism development on the society of Eilat, where there is a feel of insecurity of not perceiving the economic effects of tourism development on infra- and superstructure of region, as well as tourists having exploited local entertainment resources. The study showed the economic effects of tourism and highlighted the obvious improvement in the attitudes of citizens in Eilat towards tourism, which led to their entry as investors in tourism projects, resulting in increasing national income from tourism. The (Jafari \& Scott, 2014) study highlighted religious values, social and cultural impacts, identity building, and their impact on the role of women in the tourism industry. It is recognized that women are key participants in the tourism business market, however often controversial. For example, women have been excluded from certain occupations in the tourism industry because of traditional (religious) and social ideologies, where religion, culture and society are the main influencers on employment of women in tourism. The study pointed out the need for creating enlightening for Islam and its relationship with tourism, its effects on individual belief, where tourism is a source of social and economic development. The impact of tourism on Muslims should be treated as both hosts and guests. But it is important to bear in mind that Islam is not just a religion and certainly not just a political movement (Milmam \& Pizam, 1988; King et al., 1993; Sautter \& Leisen, 1999; Jafari \& Scott, 2014; Al-Najdawi et al., 2017).

It is a culture and civilization. It is a way of life that differs from one Muslim state to another. The social and religious principles of Islam must be recognized and the study of the mutual systematic and structural influence between the Islamic world and Tourism would strengthen the limits of knowledge in this interdisciplinary area. (Shunnaq et al., 2008; Jawabreh, 2017b) presented a study on the development of Jordanian society using a sustainable tourism strategy. A case study was carried out through the Jordan River Valley; a ten-year cooperation program between Yarmouk University and Arkansas University. The aim of the study is to develop a touristic road across the Jordan River Valley, which integrates the heritage of the valley, archeology, Christian and Islamic religious sites. The study also sought to develop the community in Umm Qais and how this program contributes to economic development in the region northern Jordan. The study revealed the attitudes of residents of Umm Qais in the north of Jordan towards tourism with its cultural, social, political and economic dimensions. The results indicated that the highest trends, accepting tourism, fall within the economic dimension, and the lowest within the social dimension. In his study, (Karatepe, 2010) pointed to the effect of positive and negative interaction between work and family on employee utilization. Does social support make a difference? By examining a conceptual model to investigate the effects of the conflict between work, family pressure, availability of individual work in families (opposing of employment) and the role of social support, being a mediator for conflict resolution. The study sample was for front office staff in the four- and five-star hotels in Albania. The results of the study proved that there is a conflict between work and family regarding job fairs for hotels, especially for females, which creates fatigue and tension within the family and weakness of employment, however, there is a positive impact of social support for work to reduce that tension. The study recommended the managers of the sample hotels to create a working environment supportive of the family, enabling the employees to effectively manage their roles at work and in their family as well, through training programs for employees 
and supervisors, focusing on strengthening social relations between work colleagues and supervisors, in order to mitigate the impact of conflict between work and family.

\subsection{The Hotel Industry}

First hotels were in the eighteenth century. In 1749, the City Hotel was the first to be established, in New York City, with 70 rooms. The world's largest and most luxurious hotel was in Boston, built in 1892. It was called Tremont House and had 170 rooms. The hotel's decor and equipment at that time were considered the beginning of the road towards formation and emergence of the modern hotel industry (Gray, 2003: 23). The analysis of hotel statistics in most countries of the world shows that number of hotels, in total, has increased in recent years by varying rates, with about 202842 hotels around the world, around $45 \%$ of them are in the United States of America. Hotels that contain more than 200 rooms are 9000 in the United States and approximately 12,000 hotels in the rest of the world, given its growing importance to members of community in addition to national economy (Chaston, 2017). The importance of the hotel industry and its characteristics can be summed up through the following main studies (Pizam, 1978; Levy \& Lerch, 1991; Kirk, 1995; Haralambopoulos \& Pizam, 1996; Walpole \& Goodwin, 2000; Henderson, 2007; Bohdanowicz \& Zientara, 2009; Sirgy et al., 2010).

\subsection{Offering Services to Individuals}

Hotels in the present age offer not only accommodation services, but all facilities and necessities, such as food and beverages, specialized restaurants, public halls, cleaning of clothes, sports clubs, nightclubs, swimming pools, shopping malls, postal and telephone services, and other services, such as secretarial and translation, etc. This is due to the diversity and different needs and desires of individuals due to the tremendous technological development, especially in the areas of transportation and communications, and the increasing leisure time (Abu Rummanetal, 2013). Today, hotels are considered one of the prerequisites of modern civilization, being social and cultural centers that meet the needs and desires of society. They allow travelers to travel day after day, hour after hour, around the globe, either for work, recreation or for other purposes away from their original home.

\subsection{Revenue and Foreign Currency}

The hotel industry is an essential part of the tourism process because of its services in the field of national economy, as a result of the funds it pumps, where it holds the lion's share of the guest's budget. Studies and research show that the individual, who visits a country, spends $32 \%$ on hotels. Analysis of hotel statistics, in most third world countries, also highlights the importance of hotels as a major source of foreign currency, to support the balance of payments in these countries. Some recent studies show that tourists keep a large part of their budgets to spend it on purchases in the countries they visit, not only to buy tourist souvenirs, but to buy some of the products and goods they find suitable, especially the products of industry and handicrafts. This expenditure is considered exportation of national products without the need for external shipping and marketing. Therefore, this export is considered free of competition difficulties in international trade, upon which, the more tourism exists, especially from the able tourists, the higher the country's export proceeds increase from tourists and visitors. Therefore, the state should pay attention to the industries and handicrafts and provide the necessary support for them to develop them and think about expanding the circle of handicrafts and folklore.

\subsection{Employment Opportunities}

The tourism industry belongs to the services industry. This means that the tourist activity is characterized by a high degree of dependence to human effort, represented by the work component. It is very difficult to replace the work element with mechanization, except within a narrow range, such as the use of electronic computers. This was confirmed by one of the French scientists, Forrest, through his theory based on a number of facts derived from nature of developing the tourism industry, where the result of theory is that the more the tourism industry is developed, the more it becomes dependent to work competent, meaning that tourism is highly capable of creating good jobs within borders of the tourism industry. The hotel industry is one of the largest industries in the world, generating jobs. It is an important source of employment, whether direct or indirect. In addition to direct employment in various economic activities of the hotel, indirect employment is provided by hundreds of industries catering to the hotel industry, beginning from structural stages, as construction provided by contracting companies, in the stage of processing, i.e. furniture, floors, decorations, kitchen appliances, elevators, etc., or in the operational phase, which, in turn, exploits the products and services of thousands of establishments, supplying all kinds of food and drink, as well as accommodation facilities, etc. (Rutherford \& O'Fallon, 2007) points out that a hotel's single room offers 20.5 jobs, divided as follows: 2.5 direct jobs and 18 indirect jobs, in the frame of food industries for hotels, i.e. meals, drinks, tools, appliances, adaptations, etc. Table (1) shows the number of employees in various tourism activities by nationality and gender for 2017. 
Table 1. Number of Employees in different Tourism Activities by Nationality \& Gender 2017

\begin{tabular}{llllllll}
\hline Item & Gender & \multicolumn{5}{l}{ Nationality } \\
\hline & Total & Female & Male & Total & Non Jordanian & Jordanian \\
Hotels & 19,398 & 1,579 & 17,819 & 19,398 & 2,164 & 17,234 \\
Tourism Restaurants & 20,009 & 1,481 & 18,528 & 20,009 & 5,617 & 14,392 \\
Travel Agencies & 4,847 & 1,349 & 3,498 & 4,847 & 93 & 4,754 \\
Rent a Car Offices & 1,755 & 0 & 1,755 & 1,755 & 30 & 1,725 \\
Tourist Shops & 1,050 & 200 & 850 & 1,050 & 45 & 1005 \\
Tourist Guides & 1,135 & 45 & 1,090 & 1,135 & & 1,135 \\
Horses Guides & 413 & 0 & 413 & 413 & 0 & 413 \\
Tourist Transpor. Comp. & 1,047 & 28 & 1,019 & 1,047 & 47 & 1,000 \\
Diving Centers & 148 & 0 & 148 & 148 & 38 & 110 \\
Water Sports & 255 & 0 & 255 & 255 & 51 & 204 \\
Total 2017 & 50,057 & 4,682 & 45,375 & 50,057 & 8,085 & 41,972 \\
Relative Weight \% & $100.0 \%$ & $9 \%$ & $91 \%$ & $100.0 \%$ & $16.2 \%$ & $83.8 \%$ \\
\hline
\end{tabular}

Source: Ministry of Tourism \& Antiquities February-2017

\subsection{Personnel Training in the Hotel Field}

Hotels play an important role in the build-up of employees and non-workers and training them, whether administrators, technicians or students, in the various divisions of a hotel in addition to other related fields, in order to increase their competence and knowledge of work and develop their skills and encouragement, in order to do their work in the best and least effort and cost possible, using the most important methods of education and training, including: (build-up and training during work, education and training through lectures and seminars, and hotel training for those wishing to enroll in hotel and tourism hotel programs). The practical reality emphasizes that human skill is an important factor in the success of any hotel, therefore requires varying abilities of expertise, skill and training. (Rudez \& Mihalic, 2007) adds that the human element is the most important capital to be invested in a hotel, where the hotel's operational sections are the Room Division and the Food and Beverage section. The human element in the hospitality industry is indispensable, because it depends on the provision of intangible services. Therefore, we need to rehabilitate the human element at hotels, in terms of behavior and professionalism, simultaneously, in order to be able to perform tasks and duties entrusted to them to the fullest, and this is primarily through training and development programs.

Development projects are often and mainly implemented in large, densely populated cities, at the expense of small cities as well as rural and remote areas. While urban dwellers enjoy all the necessities of modern life, the populations of small towns and rural areas are severely underdeveloped, resulting in inequitable distribution of development and income. Andriotis (2002) finds that tourism development provides fair distribution of income and development projects in all remote areas in addition to small and large cities, particularly road and transport projects, and services such as markets, hotels, restaurants, tourist facilities and others. This is illustrated by the development of geographical areas, where tourism and hotel projects are invested in economic, environmental and social aspects through the development of infrastructure, job creation, reduction of unemployment, mixing the local community with tourist and hotel facilities, and informing them of their cultures, customs and traditions.

\subsection{Developing many Industries Necessary, Complementary and related to Growth and Success of Hotel Activity}

Tourism has a high capacity of creating a series of productive processes and activities, because of the complex and direct tourist demand on the majority of branches and industry's of the national economy. It contributes to the establishment of many secondary and side industries that relate to more than 150 different industries, e.g. Food and beverage industries, handicrafts and others. Consequently, the effects of tourism extend to other industry s and thus serve as a powerful engine for the national economy of countries.

Hotel activity has several characteristics that distinguish it from other industry s, which is highlighted by (Kirk, 1995; Al-Jumaily, 2015). These features are as follows:

1. Hotel activity is influenced by events relating to political stability and security fluctuations, where any events in a country may affect the entire region.

2. The sensitivity of hotel activity towards economic conditions of the countries exporting tourists. The strong currency enables its citizens and owners to travel and spend generously in countries suffering from the 
depreciation of their currency.

3. Success in the hotel industry is measured by the level of service provided. This requires constant measurement of customer satisfaction with these services.

4. The urgent need for the human element in hotel work, as it is an essential element in the hotel industry, because the hotel service is through direct dealing with the guests, and thus emerges the difficulty of relying on machines.

5. The need for a professional management, capable of coordination, to ensure effective delivery of various services and activities.

6. Hotel activity is characterized by continuous service system throughout the day with non-stop approach.

7. It isSeasonal, so demand for hotel services is sometimes high and low at other times.

\subsection{Local Community Concept}

There have been many ideas about the concept of the community and the nature of the elements that constitute it; however, they all agreed that community is the group of individuals and organizations surrounding the facility. Sirgy et al. (2010) say that the term community does not include all individuals and organizations that affect and are affected by it. Another definition is that the community includes not only individuals but also organizations and institutions located in a limited place (Kayastha, 1997; Joseph \& Kavoori, 2001; Wood, 2008; Legrand et al., 2016). The community has also been identified as a population, whose life is of a general cultural nature with common interests and goals, a set of similar social values, rules of custom, collective behavior and mutual services that inspire a sense of belonging to it and loyalty to their community as part of a larger society (Brunt \& Courtny, 1999), it is also known as part of the total society, which is small community management constituted by a group of people in a well-defined geographical, historical and political environment, as well as defined boundaries (McKercher, 1993; Chandralal, 2010). The community is the eye of the whole society. Therefore, it is the clear picture, the actual ruling power progress, the form of progress, awareness and understanding among the members of this society. It is local, because it deals directly with the components of this society. It is, in its administrative form, part of civil society associations, or non-governmental organizations (Thomson et al., 2011; Roy et al., 2015).

The rate of tourism income in Jordan recorded high growth rates in the past years. Jordan's tourism income in 2016 increased by $14.5 \%$ compared to 2015 , and Table (2) shows this.

Table 2. Monthly tourism income for the years 2016 - 2017 by million JD

\begin{tabular}{llll}
\hline Month & \multicolumn{2}{c}{ Receipts } & \multicolumn{1}{c}{ \% Relative Change } \\
\hline & 2016 & 2017 & $17 / 16$ \\
January & 232.3 & 260.7 & $12.2 \%$ \\
February & 165.5 & 201.6 & $21.8 \%$ \\
March & 216.3 & 238.2 & $10.1 \%$ \\
1st Qrtr & 614.10 & 700.50 & $14.1 \%$ \\
April & 242.5 & 309.2 & $27.5 \%$ \\
May & 246.6 & 263.4 & $6.8 \%$ \\
June & 196.9 & 215.6 & $9.5 \%$ \\
2nd Qrtr & 686.0 & 788.2 & $14.9 \%$ \\
Total & 1300.1 & 1488.7 & $14.5 \%$ \\
\hline
\end{tabular}

Source: Ministry of Tourism \& Antiquities February-2017

\subsection{Aqaba Tourist Attractions}

The World Tourism Organization (WTO) has announced, on its website, the selection of the city of Aqaba as the world's best tourist destination; one of the most important international sites in providing model tourism for all people including people with disabilities, quoted from Aqaba Special Economic Zone Authority (ASEZA) http://www.aseza.jo

According to researcher in the history of Aqaba (Al-Shqour, 2015), Aqaba has many tourist advantages that qualify it to be one of the most important tourist resorts in the Arab world.

The most important of these advantages: 
1. Aqaba's strategic location on the borders of several countries and on the Gulf coast, in addition to proximity to local tourist places and neighboring countries.

2. Easy access to Aqaba by land, sea and air. Aqaba has a modern international airport, a modern passenger port and a modern road network.

3. It is located on the Gulf of Aqaba coast, which is characterized by its purity, calmness and cleanliness, and its great diversity of coral, fish and marine life that are not found in other seas and oceans.

4. The availability of tourism, heritage, historical and archeological elements, such as the castle, the historic city of Ela, Tal el-Khulaifi, Tel Al-Maks, Beit Sharif, Hussein bin Ali and others.

5. The availability of modern tourist sub- and superstructure. The city has more than 50 tourist hotels, more than 40 well-known tourist restaurants, 50 Oriental and heritage shops, 35 tourist offices and more.

6. The possibility of practicing various sports and tourism activities, such as diving, snorkeling, mountaineering, paragliding, horseback riding and beauty.

All these advantages are the most important reasons and incentives for the adoption of the city as a special economic zone, which led to many large investments as reported by the Aqaba Economic Zone Authority Commission on its website on 13/03/2008, as well as Aqaba Development Company (www.adc.jo) (Tala Bay, Red Sea Resort, Tala Hills, Aqaba Castle Exhibitions, 3 Star Hotels, Oasis of Ela, Saraya Aqaba Project, MarsaZayed Project).

The number of investment projects coincides with the launch of the national tourism strategy, aimed at attracting 4.8 million tourists. The contribution of tourism to the national income reached $11 \%$ in 2015 , and the head of Aqaba Special Economic Zone Authority, HE Nasser Sherida, said that the tourism projects in Aqaba will provide, over the next three years, 10000 jobs specialized in the field of tourism. And that the completion of these projects will provide more than 2000 hotel rooms added to the rest of the rooms, to reach, in total, more than 6000 hotel rooms.

\section{Study Methodology}

\subsection{Study Population and Sample}

The study community consisted of a group of local community members in the city of Aqaba. The questionnaire was distributed in a manner that ensures the diversity of the selection of respondents in terms of gender, age, marital status, income, and academic and professional qualifications. In September 2017, 250 questionnaires were distributed, and 222 questionnaires were retrieved, representing $89 \%$ of the distributed questionnaires. After the initial review of the questionnaire, the number of valid questionnaires for the analysis was 206. Table 3 presents the general framework of the studied population.

Table 3. The general framework of the studied population

\begin{tabular}{lll}
\hline Demographic Inf. & Frequency & percentage \\
\hline Gender & & \\
Male & 124 & $\% 60.2$ \\
Female & 82 & $\% 39.8$ \\
Total & 206 & $\% 100$ \\
Age & & \\
Less than 18 year & 26 & $\% 12.6$ \\
$30-18$ & 110 & $\% 53.4$ \\
$39-31$ & 34 & $\% 16.5$ \\
$49-40$ & 21 & $\% 10.2$ \\
$59-50$ & 10 & $\% 4.9$ \\
60 and more & 5 & $\% 2.4$ \\
Total & 206 & $\% 100$ \\
Marital status & &
\end{tabular}




\begin{tabular}{lll} 
Single & 119 & $\% 57.8$ \\
Married & 87 & $\% 42.2$ \\
Total & 206 & $\% 100$ \\
Income/ JD & & \\
Less than 250 & 114 & $\% 55.3$ \\
$500-251$ & 58 & $\% 28.2$ \\
$750-501$ & 18 & $\% 8.7$ \\
$1000-751$ & 12 & $\% 5.8$ \\
$1250-1001$ & 2 & $\% 1$ \\
More than1251 & 2 & $\% 1$ \\
Total & 206 & $\% 100$ \\
Educational Qualification & & \\
Secondary school or less & 77 & $\% 37.4$ \\
Diploma & 38 & $\% 18.4$ \\
Bachelor & 74 & $\% 35.9$ \\
Higher study & 17 & $\% 8.3$ \\
Total & 206 & $\% 100$ \\
Carrere & & $\% 100$ \\
Student & 61 & $\% 29.6$ \\
Privet industry & 45 & $\% 21.8$ \\
Public Industry & 79 & $\% 38.3$ \\
Without job & 21 & $\% 10.2$ \\
Total & 206 & $\% 100$ \\
\hline
\end{tabular}

Table (3) shows the general framework of the studied population, where $60.2 \%$ of the study sample was male, $53.4 \%$ were in the age group (18-30) years, $57.8 \%$ were non-married, and $55.3 \%$ of the respondents reported that their income is less than JD 250 per month. The graduates of the high school and the bachelor's degree ranked first among the respondents in the scientific qualification index, respectively (37.4\% and 35.9\%). Finally, the percentage of respondents from the public industry was $38.3 \%$ the highest percentage of the profession index.

\subsection{Measures}

The questionnaire consists of two main parts:

Part 1: Discussing the demographic information on the sample, such as age, gender, social status, educational level, and monthly income.

The second part included the study variables related to the Aqaba community's view of hotel work, in terms of customs and traditions, gender, religion, cultural awareness and family. These variables were expressed in 33 presentational phrases, which were linked to the five-dimensional "Likert" As follows: (Strongly agree, agree, agree to some extent, disagree, do not agree at all), assign grades $(1,2,3,4,5)$, respectively.

To test the hypotheses of the study, a series of statistical analysis methods were used. Recurrence tables and percentages were used to measure the respondents' view of hotel work, standard deviations to measure the dispersion of values around their computational settings, "T test" was used to reject or accept the study hypotheses related to the five main dimensions of the study. Also, $\mathrm{R}^{2}$ was used to determine the effect of the independent variables on the estimates of the sample members.

\subsection{Study Hypotheses}

The study included one main hypothesis, of which five sub-hypotheses are derived, namely:

-The main hypothesis: 
There is no statistically significant effect at the level of $(\alpha \leq 0.05)$ of the local Aqaba community on the decision of its members to work in the hotel industry.

-Sub-assumptions:

1 -There is no statistically significant effect at the level $(\alpha \leq 0.05)$ of the customs and traditions of local Aqaba society on the decision of its members to work in the hotel industry.

2- There is no statistically significant effect at the level of $(\alpha \leq 0.05)$ of gender factor in the local Aqaba society on the decision of its members to work in the hotel industry.

3 -There is no statistically significant effect at the level of $(\alpha \leq 0.05)$ of religion factor in the local Aqaba society on the decision of its members to work in the hotel industry.

4- There is no statistically significant effect at the level of $(\alpha \leq 0.05)$ of cultural awareness factor in Aqaba local society on the decision of its members to work in the hotel industry.

5 - There is no statistically significant effect at the level of $(\alpha \leq 0.05)$ of family factor in Aqaba local society on the decision of its members to work in the hotel industry.

\section{Study Findings and Discussion}

\subsection{Results Analysis and Display}

This analysis aims at identifying the nature of the computational environment, the standard deviations, and the correlation coefficients of the responses to the study variables within the second questionnaire. As shown in Tables (4) to (12).

The researcher relied on the following gradient in the judgment on degree of rating of the study sample on each of the paragraphs of the questionnaire:

1. Less than 1.50 degrees of rating is very little.

2. From 1.50 - 2.49 degrees is little.

3. From 2.50 - 3.49 is medium score.

4. From 3.50 to 4.49 degrees is high.

5.50 and above is a very high degree of rating.

(1) Customs and traditions:

Table 4. Means and standard deviations of the ratings of the sample members in the field of customs and traditions

\begin{tabular}{|c|c|c|c|c|}
\hline No. & Statement & Mean & $\begin{array}{l}\text { Standard } \\
\text { Deviations }\end{array}$ & Rating \\
\hline 1 & $\begin{array}{l}\text { Work in the hotel industry is considered default from the society's } \\
\text { point of view for both males and females }\end{array}$ & 2.80 & 1.03 & Medium \\
\hline 2 & Community looks lowly to men who work in the hotel industry & 2.49 & 0.98 & Medium \\
\hline 3 & Community looks lowly to women in the hotel industry & 3.07 & 1.32 & Medium \\
\hline 4 & $\begin{array}{l}\text { Customs and traditions of society impose on people not to work in the } \\
\text { hotel industry because of tribalism and ethnicity }\end{array}$ & 3.06 & 1.09 & Medium \\
\hline 5 & $\begin{array}{l}\text { Community rejects hotel work for fear of criticizing relatives, friends } \\
\text { and acquaintances }\end{array}$ & 2.64 & 0.99 & Medium \\
\hline 6 & $\begin{array}{l}\text { Customs and traditions of the community reject the idea of working in } \\
\text { the hotel industry, because a hotel serves guests for certain amounts, } \\
\text { while hospitality of the Arab people is based on the guest service free } \\
\text { of charge }\end{array}$ & 2.19 & 1.00 & Medium \\
\hline 7 & $\begin{array}{l}\text { Customs and traditions of society reject the idea of working in the } \\
\text { hotel industry for fear of recession of morality due to mixing and } \\
\text { openness with foreign guests }\end{array}$ & 2.86 & 1.12 & Medium \\
\hline \multicolumn{2}{|c|}{ In Total } & 2.73 & 1.07 & Medium \\
\hline
\end{tabular}

Table (4) shows the Means and standard deviations of the ratings of sample members in the field of customs and 
traditions. The total rating of the fields was 2.73 and the standard deviation (1.07) corresponding to statement (3), which states that "Community looks lowly to women in the hotel industry" with an average of 3.07 and a standard deviation (1.32) within a medium rating, while the lowest averages were in paragraph (6) which states" Customs and traditions of the community reject the idea of working in the hotel industry, because a hotel serves guests for certain amounts, while hospitality of the Arab people is based on the guest service free of charge" with an average of 2.19 and a standard deviation of (1.00), within a medium rating.

Table 5. Average and standard deviations of the rating of the sample members in the gender field

\begin{tabular}{lllll}
\hline No. & Statement & Mean & $\begin{array}{l}\text { Standard } \\
\text { Deviations }\end{array}$ & Rating \\
\hline 8 & $\begin{array}{l}\text { Community looks negatively at men, who work in the hotel industry, } \\
\text { because he may serve others for a certain amount }\end{array}$ & 2.43 & 0.90 & Little \\
9 & $\begin{array}{l}\text { Men are more suitable to work in the hotel industry than women, } \\
\text { because the working environment in hotels is mostly male }\end{array}$ & 3.24 & 1.12 & Medium \\
$10 \quad \begin{array}{l}\text { Community rejects the idea of women working in the hotel industry } \\
\text { because of the mere fact that they are women }\end{array}$ & 2.71 & 1.21 & Little \\
$11 \quad \begin{array}{l}\text { Community rejects the idea of women's work in the hotel industry } \\
\text { because it can't carry out the tasks and duties entrusted to it at work }\end{array}$ & 2.24 & 0.99 & Medium \\
$12 \quad \begin{array}{l}\text { Women's work in the hotel industry contributes to the activation of } \\
\text { their role as a vital element in all industry s of work within the } \\
\text { community }\end{array}$ & 3.10 & 1.42 & Medium \\
\hline
\end{tabular}

Table (5) shows the Mean and standard deviations of the ratings of sample members in the gender field. Statement (9), which states that "Men are more suitable to work in the hotel industry than women, because the working environment in hotels is mostly male" scored highest average of 3.24 and a standard deviation (1.12) within a medium rating, while statement (11), which states that "Community rejects the idea of women's work in the hotel industry, because it cannot carry out the tasks and duties entrusted to it at work" scored lowest average of 2.24 and a standard deviation (0.99) within a low rating. General average of all field statements was (2.74) and a standard deviation (1.23), within a medium rating.

Table 6. Mean and standard deviations of the ratings of sample members in the field of religion

\begin{tabular}{lllll}
\hline No. & Statement & Mean & $\begin{array}{l}\text { Standard } \\
\text { Deviations }\end{array}$ & Rating \\
\hline 13 & $\begin{array}{l}\text { Community rejects the work of a person in the field of hotels because } \\
\text { it is Islamic prohibited "Haraam" }\end{array}$ & 3.05 & 1.34 & Medium \\
14 & $\begin{array}{l}\text { Community refuses to work in hotels because they believe that their } \\
\text { income is haraam due to the bar that serves alcoholic beverages }\end{array}$ & 3.45 & 1.13 & Medium \\
15 & $\begin{array}{l}\text { Community refuses to work in hotels because of the mixing of the } \\
\text { sexes at work, which may be forbidden by the Islamic religion }\end{array}$ & 3.31 & 1.25 & Medium \\
$16 \quad \begin{array}{l}\text { Community refuses to work in hotels because of the Western customs } \\
\text { and traditions related to improvisation, Non-Shariah'a dress, and the } \\
\text { false openness of men to women }\end{array}$ & 3.49 & 1.01 & Medium \\
$17 \quad \begin{array}{l}\text { Community refuses to work in hotels, because these hotels are owned } \\
\text { by foreign hotel chains }\end{array}$ & 2.78 & 1.27 & Medium \\
In Total & 3.21 & 1.20 & Medium \\
\hline
\end{tabular}

Table (6) shows the statistical averages and standard deviations of the respondents' rating in religion field. Statement (16) states that "Community refuses to work in hotels because of the Western customs and traditions related to improvisation, non-Shariah'a dress, and the false openness of men to women" scored the highest average of (3.49) and standard deviation (1.01) within the medium rating, while statement (17), which states that "Community refuses to work in hotels, because these hotels are owned by foreign hotel chains" scored lowest rating of 2.78 and a standard deviation (1.27) within a medium rating. General average of all field statements 
was (3.21) and a standard deviation (1.20), within a medium rating.

Table 7. Mean and standard deviations of ratings of the sample members in the field of cultural awareness

\begin{tabular}{|c|c|c|c|c|}
\hline No. & Statement & Mean & $\begin{array}{l}\text { Standard } \\
\text { Deviations }\end{array}$ & Rating \\
\hline 18 & There is lack of cultural awareness among families about hotels & 3.89 & 0.99 & High \\
\hline 19 & $\begin{array}{l}\text { The community lacks tourist outreach programs that illustrate the } \\
\text { nature of business in hotels }\end{array}$ & 3.64 & 1.09 & High \\
\hline 20 & $\begin{array}{l}\text { Cultural level and low educational attainment of some families in the } \\
\text { community making them unwilling to work in the hotel industry }\end{array}$ & 3.34 & 0.98 & Medium \\
\hline 21 & $\begin{array}{l}\text { The lack of awareness concerning importance of the role of tourism in } \\
\text { terms of strengthening their jobs making them unwilling to work in } \\
\text { hotels }\end{array}$ & 3.56 & 0.94 & High \\
\hline 22 & $\begin{array}{l}\text { There is lack of awareness in the community concerning the national } \\
\text { economic importance of hotel work }\end{array}$ & 3.81 & 1.01 & High \\
\hline 23 & $\begin{array}{l}\text { Low cultural level of the members of the community prevents them } \\
\text { from working in the hotel industry, because they are unable to adapt to } \\
\text { the needs and requirements of work in hotels }\end{array}$ & 3.24 & 1.04 & Medium \\
\hline 24 & $\begin{array}{l}\text { Difficulty of speaking foreign language with foreign tourists is a } \\
\text { barrier that does not allow community members to work in hotels }\end{array}$ & 3.61 & 1.14 & High \\
\hline 25 & $\begin{array}{l}\text { Community views tourism and hotel study as particularly negative } \\
\text { from a social point of view }\end{array}$ & 2.98 & 0.97 & Medium \\
\hline 26 & $\begin{array}{l}\text { There is lack of awareness of the importance of the role of tourism in } \\
\text { the development of the capabilities of individuals and employees in } \\
\text { hotels, in terms of personality, better behavior, and dealing with } \\
\text { important persons and individuals in the community }\end{array}$ & 3.48 & 1.05 & Medium \\
\hline \multicolumn{2}{|c|}{ In Total } & 3.50 & 1.02 & High \\
\hline
\end{tabular}

Table (8) shows the Mean and standard deviations of the sample ratings in the cultural awareness field. Statement (18), which states that "There is lack of cultural awareness among families about hotels", scored highest average of 3.89 and a standard deviation of 0.99 within high rating. Statement (25), which states that "Community views tourism and hotel study as particularly negative from a social point of view" scored the lowest average of (2.98) and standard deviation (0.97) within a medium rating. General average of all field statements was (3.50) and a standard deviation (1.02), within high rating.

Table 8. Mean and standard deviations of the ratings of the sample members in the family field

\begin{tabular}{|c|c|c|c|c|}
\hline No. & Statement & Mean & $\begin{array}{l}\text { Standard } \\
\text { Deviations }\end{array}$ & Rating \\
\hline 27 & $\begin{array}{l}\text { The family believes that the woman's place is at home and should not } \\
\text { work anywhere else, including the hotel }\end{array}$ & 2.73 & 1.10 & Medium \\
\hline 28 & $\begin{array}{l}\text { The family does not want family members to work in the hotel } \\
\text { industry fearing for their safety due to security instability and the } \\
\text { recent bombings in hotels }\end{array}$ & 2.36 & 1.18 & Little \\
\hline 29 & The family rejects the idea of family girls studying hotel specialties & 3.30 & 1.12 & Medium \\
\hline 30 & $\begin{array}{l}\text { The family refuses to let their members (especially females) work at } \\
\text { hotels fearing from sexual harassment by visitors and guests at the } \\
\text { hotel }\end{array}$ & 3.63 & 1.16 & High \\
\hline 31 & $\begin{array}{l}\text { The family refuses that their members (especially females) work at } \\
\text { hotels, because work may require staying outside their home }\end{array}$ & 3.53 & 1.11 & High \\
\hline 32 & $\begin{array}{l}\text { The family refuses to let their members (especially females) work at } \\
\text { hotels fearing from of sexual harassment by their employees }\end{array}$ & 3.32 & 1.37 & Medium \\
\hline 33 & $\begin{array}{l}\text { Due to lack of employment, family members work in the hotel } \\
\text { industry }\end{array}$ & 3.03 & 1.28 & Medium \\
\hline \multicolumn{2}{|c|}{ In Total } & 3.12 & 1.18 & Medium \\
\hline
\end{tabular}


Table (9) shows the Mean and standard deviations of the ratings of sample members in the family field. Statements (30) states that "The family refuses to let their members (especially females) work at hotels fearing from sexual harassment by visitors and guests at the hotel" scored the highest average of (3.63) and standard deviation (1.16) within high rating, while statement (28), which states that "The family does not want family members to work in the hotel industry fearing for their safety due to security instability and the recent bombings in hotels" scored the lowest average of (2.36) and a standard deviation (1.18) within little rating. General average of all field statements was (3.12) and a standard deviation (1.18), within a medium rating.

Table 9. Mean and the standard deviations of the ratings of sample members in the study fields and the used tool in total

\begin{tabular}{lllll}
\hline No. & Field & Mean & Standard Deviations & Rating \\
\hline & & & & \\
1 & Customs and Traditions & 2.73 & 1.07 & Medium \\
2 & Gender & 2.74 & 1.23 & Medium \\
3 & Religion & 3.21 & 1.20 & Medium \\
4 & Cultural Awareness & 3.50 & 1.02 & High \\
5 & Family & 3.12 & 1.18 & Medium \\
Tool in Total & 3.06 & 1.14 & Medium \\
\hline
\end{tabular}

Table (9) shows the statistical averages and standard deviations of the respondents' ratings in the study fields and the used tool in total. The field of cultural awareness scored the highest average of (3.50) and the standard deviation (1.02). The obstacle to work in hotels is the continuous lack of cultural awareness, followed by other fields of religion, family, sex and customs and traditions. The general average of the study sample on the tool total is 3.06 within medium rating. This means that work local hotels still lacks awareness.

\subsection{Hypotheses Test}

To test the hypotheses, the T-test was used at the significance level (0.05):

Table 10. Mean standard deviations and the T-test on individuals of the study sample in the study fields and the used tool in total

\begin{tabular}{|c|c|c|c|c|c|c|c|}
\hline Field & Mean & $\begin{array}{l}\text { Standard } \\
\text { Deviations }\end{array}$ & $\begin{array}{l}\text { Degree } \\
\text { Freedom } \\
(\mathrm{n}-1)\end{array}$ & of & $\begin{array}{l}\text { Calculated } \\
\text { t-value }\end{array}$ & $\begin{array}{l}\text { t-Table } \\
\text { Value }\end{array}$ & $\begin{array}{l}\text { significance } \\
\text { level }\end{array}$ \\
\hline $\begin{array}{ll}\text { Customs } & \text { and } \\
\text { Traditions } & \end{array}$ & 2.73 & 1.07 & 205 & & 1.84 & 2.576 & 0.005 \\
\hline Gender & 2.74 & 1.23 & 205 & & 2.48 & 2.576 & 0.002 \\
\hline Religion & 3.21 & 1.20 & 205 & & 2.43 & 2.576 & 0.015 \\
\hline $\begin{array}{l}\text { Cultural } \\
\text { Awareness }\end{array}$ & 3.50 & 1.02 & 205 & & 2.26 & 2.576 & 0.000 \\
\hline Family & 3.12 & 1.18 & 205 & & 1.77 & 2.576 & 0.000 \\
\hline Tool in Total & 3.06 & 1.14 & 205 & & 1.95 & 2.576 & 0.002 \\
\hline
\end{tabular}

4.2.1 The Main Hypothesis Test: There is no statistically significant effect at the level of $(\alpha \leq 0.05)$ in the local Aqaba community on the decision of its members to work in the hotel industry

Table (10) shows that the calculated value of $t$ is 1.59 , since it is less than the $t$ (critical) value. Therefore, we fail to reject the main hypothesis, that the community's view in Aqaba does not encourage its members to engage in hotel work. This is confirmed by previous hypotheses that the community in Aqaba does not encourage their members to engage in hotel work, because of customs and traditions, gender, religion, lack of cultural awareness, and the family. This may all be due to lack of cultural awareness among community members concerning the nature of work at hotels, and here it is necessary to increase interest in this area through the means available.

4.2.2 First Sub-Hypothesis Test: There is no statistically significant effect at the level of ( $\alpha \leq 0.05)$ of customs and traditions of the local Aqaba community on the decision of its members to work in the hotel industry

Table (10) shows that the calculated value of $t$ is 1.84 , since it is less than the tabular (critical) value. Therefore, 
we fail to reject the first hypothesis, in the sense that the customs and traditions of the community in Aqaba do not encourage participation in hotel work, to the fact that the Jordanian society is one of the conservative societies that is adhering to customs and traditions. There are many different jobs that are still discouraged, such as the profession of nursing, especially for females. This is also the problem of the hotel industry, where the outlook is still below the desired level, to the fear of mixed interaction, which results from the nature of work in the field of hotels. As it requires openness and mingle with guests, especially foreigners, and requires awareness of the local community, as such things matter.

4.2.3 Second Sub-Hypothesis Test: There is no statistically significant effect at the level $(\alpha \leq 0.05)$ of gender factor in the local Aqaba community on the decision of its members to work in the hotel industry

Table (10) shows that the calculated value of $t$ is 2.48 , since it is less than the $t$ (critical) value. Therefore, we fail to reject the second hypothesis, meaning that the view of the community in terms of gender does not encourage participation in hotel work. To the negative perception, seen by the community towards both men and women, who work in the hotel industry, as well as the Arab customs and traditions that characterize the Jordanian society and reinforce this negative view, the fact is that the vast majority of families are from conservative origins, the same applies towards working in hotels, even if it was on the account of their members, who are waiting for a long time to find a job at government and private industry in addition to non-hotel industry , despite the economic feasibility, resulting from work in the hotel industry.

4.2.4 Third Sub-Hypothesis Test: There is no statistically significant effect at the level of $(\alpha \leq 0.05)$ of religion factor in the local Aqaba community on the decision of its members to work in the hotel industry

Table (10) shows that the calculated value of $t$ is 2.43 , since it is less than the $t$ (critical) value. Therefore, we fail to reject the third hypothesis, meaning that the view of the community, in terms of religious beliefs, does not encourage engagement in hotel work. The result is that the prevailing religion among the members of the community in the city of Aqaba is the Islamic religion, through which the members of the community view the work in hotels as Islamic prohibited "haraam" or almost forbidden, and the members of society refuse to work in hotels, because they believe that their income is also haraamm, due to prohibition of Alcoholic beverages at bars, moreover, openness in hotel work, and the mixing of workers and close interaction between the inmates.

4.2.5 Fourth Sub-Hypothesis Test: There is no statistically significant effect at the level of $(\alpha \leq 0.05)$ of cultural awareness factor in the local Aqaba community on the decision of its members to work in the hotel industry

Table (10) shows that the calculated $t$ value is (2.26), since it is less than the $t$ (critical) value. Therefore, we fail to reject the fourth hypothesis, meaning that the community's view of cultural awareness does not encourage engagement in hotel work. The result is that there is a lack of cultural awareness among the families regarding hotels and their areas of work. There are many sections where women can work, such as a linen supervisor, secretary, an officer in a linen room, Dyeing personnel, shift coordinator, Hotel management, floor supervisor, room cleaner, room employee, party supervisor and other functions, which fit the nature of women. In addition, there is lack of awareness in the community concerning the national economic importance of hotel work and the resulting profits and positive impact on the Jordanian economy as well as the national income of Jordan, as a result of tourist attractions in addition to the recovery of other economic industry $\mathrm{s}$ in various fields such as transportation, among others. It is necessary to increase the interest in educating the local community about the importance of hotels on the economic aspect, on the one hand, and on the other hand, it helps reducing the unemployment, suffered by the Jordanian society, through the job opportunities provided by the hotel industry. This is done through various media, pamphlets and campaigns.

4.2.6 Fifth Sub-Hypothesis test: There is no statistically significant effect at the level of $(\alpha \leq 0.05)$ of family factor in the local Aqaba community on the decision of its members to work in the hotel industry

Table (10) shows that the calculated value of $t$ is 1.37 , since it is less than the $t$ (critical) value. Therefore, we fail to reject the fifth hypothesis, meaning that the view of the community, in terms of family, does not encourage engagement in hotel work. The families refuse to be sexually harassed by visitors and guests at the hotel, "The family refuses that their members (especially females) work at hotels, because work may require staying outside their home", where this does not encourage the family to promote its members (especially females) to work at hotels, perhaps due to lack of cultural awareness, the customs and traditions, religion and sex.

\subsection{Test the Effect of Independent Variables on the Estimates of Respondents}

In order to determine, whether there are statistically significant differences between the ratings of individuals in the study sample, according to the variables (gender, age, marital status, monthly income, scientific qualification, occupation), the researcher used single-variance analysis, as shown in table (11) for explanation: 
Table 11. Single-variance Analysis Test

\begin{tabular}{|c|c|c|c|c|c|c|}
\hline Variable & $\begin{array}{l}\text { Source } \\
\text { Variance }\end{array}$ & $\begin{array}{l}\text { Squares } \\
\text { Total }\end{array}$ & $\begin{array}{l}\text { Degree } \\
\text { Freedom } \\
\end{array}$ & of & $\begin{array}{l}\text { Squares } \\
\text { Average }\end{array}$ & $\mathrm{F}$ \\
\hline \multirow[t]{3}{*}{ Gender } & Between groups & 11.196 & 1 & & 11.196 & $4.003^{*}$ \\
\hline & Within group & 38.163 & 204 & & .200 & \\
\hline & Total & 49.359 & 205 & & & \\
\hline \multirow[t]{3}{*}{ Age } & Between groups & 173.880 & 5 & & 12.420 & $25.905^{*}$ \\
\hline & Within group & 91576 & 200 & & .479 & \\
\hline & Total & 265.456 & 205 & & & \\
\hline \multirow[t]{3}{*}{ Marital Status } & Between groups & 43.831 & 1 & & 43.831 & $19.069^{*}$ \\
\hline & Within group & 31358 & 204 & & 164 & \\
\hline & Total & 75.189 & 205 & & & \\
\hline \multirow[t]{3}{*}{ Income } & Between groups & 137.628 & 5 & & 9.831 & $24.692 *$ \\
\hline & Within group & 76.042 & 200 & & .398 & \\
\hline & Total & 213.670 & 205 & & & \\
\hline Scientific & Between groups & 99.550 & 3 & & 33.183 & $11.367^{*}$ \\
\hline \multirow[t]{2}{*}{ Qualification } & Within group & 119.479 & 202 & & .589 & \\
\hline & Total & 99.550 & 205 & & & \\
\hline \multirow[t]{3}{*}{ Occupation } & Between groups & 126.421 & 3 & & 42.140 & $21.532 *$ \\
\hline & Within group & 80.103 & 202 & & .419 & \\
\hline & Total & 206.524 & 205 & & & \\
\hline
\end{tabular}

*Statistical significance at the level (0.05).

Table (11) shows that there are statistically significant differences between the ratings of the sample members due to gender, age, social status, income, scientific qualification and profession.

1. There are statistically significant differences between the estimates of the sample due to the gender variable. The differences were in favor of females. This result is due to the negative view of the female towards work in the hotel industry.

2. There are statistically significant differences between the estimates of the study sample due to the variable of the marital status.

3. There are statistically significant differences between the estimates of the study sample due to the variable of age.

4. There are statistically significant differences between the estimates of the study sample due to the variable of income.

5. There are statistically significant differences between the estimates of the study sample due to the variable of the scientific qualification.

6. There are statistically significant differences between the estimates of the sample members of study due to the profession variable.

4.4 Scheffe' Test

To stand on sources of the differences between the averages, the researcher used the Schiffe test for post-comparisons, as follows:

Table 1. Results of the Schiffe test for post-comparisons

\begin{tabular}{|c|c|c|c|c|c|c|c|c|}
\hline Field & Age & & $\begin{array}{l}\text { Less } \\
\text { than18 }\end{array}$ & $18-30$ & $39-31$ & $49-40$ & $59-50$ & 60 or more \\
\hline \multirow[t]{5}{*}{ Age } & & $\begin{array}{l}\text { Calculate } \\
\text { d Average }\end{array}$ & 3,37 & 3,78 & 4,27 & 2,98 & 2,74 & 3,98 \\
\hline & Less than 18 & 3,73 & & 0,41 & 0,90 & 0,39 & 0,63 & 0,61 \\
\hline & $18-30$ & 3,78 & & & 0,49 & 0,80 & 1,04 & 0,20 \\
\hline & $31-39$ & 4,27 & & & & 1,29 & $1,53 *$ & 0,29 \\
\hline & $40-49$ & 2.98 & & & & & 0,24 & 1,00 \\
\hline
\end{tabular}




\begin{tabular}{|c|c|c|c|c|c|c|c|c|}
\hline & $50-59$ & 2,74 & & & & & & 1,24 \\
\hline & 60 or more & 3,98 & & & & & & \\
\hline Field & Income & & $\begin{array}{l}\text { Less } \\
\text { than25 } \\
0\end{array}$ & $\begin{array}{l}251-50 \\
0\end{array}$ & $\begin{array}{l}507-75 \\
0\end{array}$ & $\begin{array}{l}751-100 \\
0\end{array}$ & $\begin{array}{l}1001-125 \\
0\end{array}$ & $\begin{array}{l}\text { More } \\
\text { than1251 }\end{array}$ \\
\hline \multirow[t]{6}{*}{ Income } & & $\begin{array}{l}\text { Calculate } \\
\text { d Average }\end{array}$ & 3,33 & 3,87 & 4,20 & 3,02 & 2,97 & 3,75 \\
\hline & $\begin{array}{l}\text { Less than } \\
250\end{array}$ & 3,33 & & 0,54 & 0,87 & 0,31 & 0,36 & 0,42 \\
\hline & $251-500$ & 3,87 & & & 0,33 & 0,85 & 0,90 & 0,12 \\
\hline & $501-750$ & 4,29 & & & & 0,18 & $* 1,23$ & 0,45 \\
\hline & $751-1000$ & 3,02 & & & & & 0,05 & 0,73 \\
\hline & $1000-1250$ & 3,75 & & & & & & \\
\hline Field & $\begin{array}{l}\text { Scientific } \\
\text { Qualificatio } \\
\mathrm{n}\end{array}$ & & & & $\begin{array}{l}\text { High } \\
\text { School } \\
\text { or less }\end{array}$ & $\begin{array}{l}\text { Technica } \\
1 \\
\text { Diploma }\end{array}$ & Bachelors & $\mathrm{MS} / \mathrm{PhD}$ \\
\hline $\begin{array}{l}\text { Scientific } \\
\text { Qualificatio }\end{array}$ & & $\begin{array}{l}\text { Calculate } \\
\text { d Average }\end{array}$ & & & 3,27 & 4,05 & 3,91 & 3,40 \\
\hline \multirow[t]{4}{*}{$\mathrm{n}$} & $\begin{array}{l}\text { High School } \\
\text { or less }\end{array}$ & 3,27 & & & & $* 0,78$ & 0,64 & 0,13 \\
\hline & $\begin{array}{l}\text { Technical } \\
\text { Diploma }\end{array}$ & 4,05 & & & & & 0,14 & 0,65 \\
\hline & Bachelors & 3,91 & & & & & & 0,51 \\
\hline & $\mathrm{MS} / \mathrm{PhD}$ & 3,40 & & & & & & \\
\hline Field & Occupation & & & & Student & $\begin{array}{l}\text { Private } \\
\text { Industry }\end{array}$ & $\begin{array}{l}\text { Public } \\
\text { Industry }\end{array}$ & $\begin{array}{l}\text { Unemploye } \\
\text { d }\end{array}$ \\
\hline \multirow[t]{6}{*}{ Occupation } & & $\begin{array}{l}\text { Calculate } \\
\text { d Average }\end{array}$ & & & 3,27 & 3,85 & 4,11 & 3,14 \\
\hline & Student & 3,27 & & & & 0,58 & 0,84 & 0,15 \\
\hline & $\begin{array}{l}\text { Private } \\
\text { Sector }\end{array}$ & 3,85 & & & & & 0,26 & 0,73 \\
\hline & Public & 4,12 & & & & & & $0,99 *$ \\
\hline & Sector & & & & & & & \\
\hline & $\begin{array}{l}\text { Unemploye } \\
\text { d }\end{array}$ & 3,12 & & & & & & \\
\hline
\end{tabular}

Table (12) shows the following:

1. Differences between estimates of ages (31 - 39) and those aged (50 - 59) were attributed to age in favor of estimates of ages $(31-39)$.

2. Differences between income estimates (501-750) and income-earners (1001-1250) were attributed for favor of income earners (501-750).

3. There are differences between the estimates of those having high school certificate or less and those with technical school qualification for the favor of technical school qualification.

4. There are differences between the estimates of the unemployed and the employed in the public Sector for the benefit of the employees of public Sector.

\subsection{The Correlation Between the Five Study Factors}

For the purpose of the correlation between the five study factors, Pearson Correlation Coefficient analysis was used, as shown in Table 13.

Table 13. Pearson Correlation Coefficients between the study factors

\begin{tabular}{|c|c|c|c|c|}
\hline $\begin{array}{l}\text { Customs } \\
\text { Traditions }\end{array}$ & & Gender & Religion & $\begin{array}{l}\text { Cultural } \\
\text { Awareness }\end{array}$ \\
\hline
\end{tabular}




\begin{tabular}{|c|c|c|c|c|c|c|}
\hline $\begin{array}{l}\text { Customs } \\
\text { Traditions }\end{array}$ & $\begin{array}{l}\text { Pearson } \\
\text { Correlation }\end{array}$ & 1.000 & $.333^{*}$ & $.362 *$ & .026 & $.509 *$ \\
\hline Gender & Sig. (2- tailed) & & .000 & .000 & .712 & .000 \\
\hline Religion & $\mathrm{N}$ & 206 & 206 & 206 & 206 & 206 \\
\hline Cultural Awareness & Pearson & $.333^{*}$ & 1.000 & $.297^{*}$ & .014 & $.205^{*}$ \\
\hline Customs & Correlation & & & & & \\
\hline Traditions & Sig. (2- tailed) & .000 & & .000 & .844 & .003 \\
\hline & $\mathrm{N}$ & 206 & 206 & 206 & 206 & 206 \\
\hline Gender & Pearson & $.362 *$ & $.297^{*}$ & 1.000 & .089 & $.523^{*}$ \\
\hline Religion & Sig (2-tailed) & 000 & 000 & & 203 & 000 \\
\hline Cultural Awareness & $\mathrm{N}$ & 206 & 206 & 206 & 206 & 206 \\
\hline Family & $\begin{array}{l}\text { Pearson } \\
\text { Correlation }\end{array}$ & .026 & .014 & .089 & 1.000 & .009 \\
\hline Traditions & Sig. (2- tailed) & .712 & .844 & .203 & & .897 \\
\hline Gender & $\mathrm{N}$ & 206 & 206 & 206 & 206 & 206 \\
\hline \multirow[t]{3}{*}{ Religion } & $\begin{array}{l}\text { Pearson } \\
\text { Correlation }\end{array}$ & $.509 *$ & $.502 *$ & $.523 *$ & .009 & 1.000 \\
\hline & Sig. (2- tailed) & .000 & .003 & .000 & .897 & \\
\hline & $\mathrm{N}$ & 206 & 206 & 206 & 206 & 206 \\
\hline
\end{tabular}

* There is a statistical significance at the level of $(0.01)$

Table (13) shows that there is a correlation between the customs, traditions, gender, religion and family. This relationship causes the researcher's conclusion, that the rating degree of the study sample members in fields of study came scored medium rating in the four previous factors, except for cultural awareness, which was in high rating, and this explains that customs, traditions, religion, family and gender have an effect on each other. The customs and traditions come from religion, and this explains the correlation between them, as well as gender and religion; where some of community members reject working in hotels, due to mixing between the two genders at work, which may be forbidden by Islam, and there is a relationship between gender, customs and traditions, which imposes that the society looks lowly at women who work in the hotel field.

\section{Conclusions}

The view of the local community in Aqaba does not encourage its members to work in hotels field, whether they are male or female, because of the customs, traditions and the nature of the conservative society. This came in line with the study of (Jafari \& Scott, 2014), indicating that the customs and traditions in the Islamic world are bordered by many heavenly teachings and legislations that urge to stay away from places containing Islamic prohibited transactions, such as revenue from the prohibited services. The findings of (Mansfeld, 1992) show that the development of tourism depends on the members of society within its environment and is influenced by the customs and traditions of the country both negatively and positively, according to cultural, religious and demographic factors. Community members refuse to work in hotels to a large extent because they believe that their income is "haraam" in Sharia'a, because of the bar service that offers alcohol, which is consistent with (Casswell et al., 1989; Shryock, 2004; Shunnaq et al., 2008; Neveu, 2010; Jafari \& Scott, 2014). All of them pointed out, through the results of their study, that the Islamic societies, especially the Arab ones, are warning the hotel industry, especially the five-star category, for providing alcohol services, as most of their visitors and customers are foreigners. This result contradicted the results of the study of (Gentry, 2007; Pillinger, 2016), where their study proved that European women looking for work in the tourism industry bear expenses and financial burdens for the purposes of employment in the European community. It is possible to say that the customs and traditions of the European community may impose on women to work to meet their living needs, while Islamic societies, especially Arab ones, ensure that men pay for women and meet all their needs. So that they do not need to look for work in a serious manner, the members of local community refuse to work in hotels because of the mixing of workers with each other on one hand and between them and the inmates and especially 
foreigners on the other. This rejection is largely towards of females than males. The study of (Wong \& Ko, 2009; Taylor, 2011) suggests that management needs to understand the needs and desires of employees working in the hotel, and these needs and desires are often governed by the constraints of society. Therefore, the study recommended that the society should first understand and then adapt the environment and work life according to the determinants of society. The results of the study of (King \& Milman, 1993; Joseph \& Kavoori, 2001) proved that the host society for outside tourists is often bothered by them, because of the pressure that may arise in the infrastructure of services.

On the one hand, and the difficulty of understanding the customs and traditions of foreign tourists, which may lead to misunderstanding or problems due to gender mixing and lack of knowledge of the nature of the foreign tourist community and vice versa. There is a weakness in the cultural awareness of the community regarding hotels and their work fields, especially in fields where women can work, and this is what the findings of (Brunt \& Courtney 1999; Joseph \& Kavoori, 2001) explained, where the results indicated the active role played by the community ineducating members of the local community (hosts) for tourists. This is achieved through the consolidation of the concept of accepting tourists as a complex equation in supporting the economy, by increasing the knowledge of tourist sites role and its facilities, in which the tourists seek to spend happy times. In addition to the lack of awareness in the society concerning the national economic importance of the hotel industry and its impact on other industry s, this is what the results of the study of (Kayastha, 1997; Haralambopoulos \& Pizam, 1996; Henderson, 2007) indicates, in order to understand the needs of the tourism industry and hotel and the extent, to keep pace with the rest of the developed industrial and commercial industries, achieving the provision of those needs in accordance with the required levels. The foreign language is a major obstacle for individuals to engage hotel work, and those families in the Aqaba society refuses to let its members' work, especially females, fearing from sexual harassment by guests on one hand, and mixing with workers, to a lesser extent, on the other hand. The families in Aqaba also refuse the work of their members in hotels, especially females, to a large extent, because working in hotels may require staying outside the home in the late work shifts (B \& C). These results were approved by the study of (Al-Samaan, 2002; Magabih, 2005).

\section{Recommendations}

Aqaba Special Economic Zone Authority (ASEZA) should raise the awareness of the local community in Aqaba regarding many issues related to hotel work, such as the nature of hotel work and its sections, the fields of hotel work, especially for females, employment opportunities provided by this industry to the members of society, through various media, especially visual, workshops supported by the success stories of male and female workers in hotels, who have achieved success in the various fields of work (economic, career path and Social fields), demonstrating the economic importance of the tourism industry in general and hotels in particular, and the importance of hotels in terms of job size available in the next few years, through organizing events, conferences, workshops and seminars on a continuous basis, to include as many as possible members of the community, raising the level of language centers and institutes in Aqaba city by attracting international centers and institutes such as British Council and French Cultural Center. Moreover, fighting the culture of shame, by presenting success stories to hotel workers, to motivate community members to work at hotels, and strive hard to alert hotel owners to isolate the returns of the bar and its profits from those employees, who like to withhold from their salary to avoid the ill-gotten money within salaries. Provide a greater role for the Ministry of Education to educate students in schools, through teaching curricula that deal with tourism and hotels and explain the role of tourism industry and hotels and its positive effects on the economic, social and environmental levels, in order to create awareness of the importance of this industry among members of society and fight the culture of shame, either through teaching curriculum of tourism at schools, or preparing workshops in coordination with the Ministry of Education, which will instill the roots of tourism in the students, before they reach the university stage, as recommended by the study (Al-Ajlouni, 2013).

\section{References}

Abu Rumman, M., Jawabreh, O., Alhyasat, K., \& Husam, H. (2013). The impact of work environment on the average of job turnover in five-star hotels in Al-aqaba city. Business Management and Strategy, 4(2). https://doi.org/10.5296/bms.v4i2.402

Al-Ajlouni, A. (2013). Tourism development in Jordan: A study of tourism awareness among students of private Jordanian universities case study: Irbid and Jadara universities. Majallat al-Turāth, 9, 130-159.

Alananzeh, O., Masa'deh, R., Jawabreh, O., Al-Mahmoud, A., \& Hamada, R. (2018). The impact of customer relationship management on tourist satisfaction: The case of Radisson Blue Resort in Aqaba city. Journal of Environmental Management and Tourism, 2(26), 227-240. 
Al-Hasanat, S. A., \& Hyasat, A. S. (2011). Sociocultural impacts of tourism on the local community in Petra, Jordan. Jordan Journal of Social Sciences, 4(1).

Al-Hussein, M., Jawabreh, O., Alananzeh, O., \& Ali, M. (2015). The impact of understanding the behavior of workers on the success of management, (a case study of five star hotels in Aqaba). Journal of Management Research, 7(3), 51-70. https://doi.org/10.5296/jmr.v7i3.7115.

Al-Jumaily, Q. (2015). Human resources management in tourism and hotels institutions (2nd Ed). Al Mutasem Publishing, Amman, Jordan.

Al-Najdawi, B. M., Kkaleefah, Q. Q., Shatanawi, H. S., \& Al Momani, E. M. (2017). Measuring local tourists' perceptions in the Petra city as one of seven wonders of the world. Journal of Environmental Management and Tourism, 2(18), 427-435.

Al-Samaan, R. (2002). Difficulties facing working Jordanian women. Unpublished Master Thesis, Department of Sociology, University of Jordan.

Al-Shawagfih, K., Alananzeh, O., \& Jawabreh, O. (2015). The foundations of selecting cultural tourism product in Jordan. European Scientific Journal, 11(29).

Al-Shqour, R. (2015). Aqaba castle, origin, development and evolution of Khans in Jordan: An archaeological approach. Doctoral Dissertation, Ghent University.

Amyan, M., \& Jawabreh, O. (2011). Mutual impact between tourism and the host community (a case study of Wadi Rum. European Journal of Social Sciences, 19(1).

Andriotis, K. (2002). Scale of hospitality firms and local economic development-evidence from crete. Tourism Management, 23(4), 333-341.

Aqaba Development Corporation (ADC) (2018), January, Retrieved from http://www.adc.jo

Aqaba Special Economic Zone Authority (ASEZA) (2018). January.Retrieved from http://www.aseza.jo

Bohdanowicz, P., \& Zientara, P. (2009). Hotel companies' contribution to improving the quality of life of local communities and the well-being of their employees. Tourism and Hospitality Research, 9(2), 147-158.

Brunt, P., \& Courtney, P. (1999). Host perceptions of sociocultural impacts. Annals of tourism Research, 26(3), 493-515.

Casswell, S., Gilmore, L., Maguire, V., \& Ransom, R. (1989). Changes in public support for alcohol policies following a community based campaign. Addiction, 84(5), 515-522.

Chandralal, K. P. L. (2010). Impacts of tourism and community attitude towards tourism: A case study in Sri Lanka. South Asian Journal of Tourism and Heritage, 3(2), 41-49.

Chaston, I. (2017). Entrepreneurship in technological entrepreneurship (pp. 1-24). Palgrave Macmillan, Cham.

Gentry, K. M. (2007). Belizean women and tourism work: Opportunity or impediment? Annals of Tourism Research, 34(2), 477-496.

Haralambopoulos, N., \& Pizam, A. (1996). Perceived impacts of tourism: The case of Samos. Annals of Tourism Research, 23(3), 503-526.

Henderson, J. C. (2007). Corporate social responsibility and tourism: Hotel companies in Phuket, Thailand, after the Indian ocean Tsunami. International Journal of Hospitality Management, 26(1), 228-239.

Jafari, J., \& Scott, N. (2014). Muslim world and its tourisms. Annals of Tourism Study, 44, 1-19.

Jamal, T. B., \& Getz, D. (1995). Collaboration theory and community tourism planning. Annals of Tourism Research, 22(1), 186-204.

Jawabreh, O. (2017a). Distinction of Jordan as a destination for religious tourism. Journal of Environmental Management and Tourism, 6(22), 1171-1182. https://doi.org/10.14505/jemt.v8.6(22).03

Jawabreh, O. (2017b). An exploratory study of the motives of Jordanian out bound tourism and its impact on the development of tourism in Jordan. International Journal of Applied Business and Economic Research, 15(19 Part-II), 443-467.

Jawabreh, O., Alananzeh, O., \& Shatnawi, H. (2015). Managing tourism effects for attitudes of Jordanians towards tourism: The case of Petra. European Journal of Social Sciences, 48(1).

Joseph, C. A., \& Kavoori, A. P. (2001). Mediated resistance: Tourism and the host community. Annals of Tourism 
Research, 28(4), 998-1009.

Karatepe, O. M. (2010). The effect of positive and negative work-family interaction on exhaustion: Does work social support make a difference? International Journal of Contemporary Hospitality Management, 22(6), $836-856$.

Kayastha, S. L. (1997). Tourism and environment in the Himalayan region. Geography and Environment: Regional Issues, Concept Publishing Company, New Delhi, 31-45.

King, B., Pizam, A., \& Milman, A. (1993). Social impacts of tourism: Host perceptions. Annals of Tourism Research, 20(4), 650-665.

Kirk, D. (1995). Environmental management in hotels. InternationalJournal of Contemporary Hospitality Management, 7(6), 3-8.

Legrand, W., Sloan, P., \& Chen, J. S. (2016). Sustainability in the hospitality industry: Principles of sustainable operations. Routledge.

Levy, D. E., \& Lerch, P. B. (1991). Tourism as a factor in development implications for gender and work in Barbados. Gender and Society, 67-85.

Magablih, K. (2006). The dimensions of Jordanian women employees in the tourism industry. Yarmouk University Journal, 95-122.

Mansfeld, Y. (1992). Group-differentiated perceptions of social impacts related to tourism development. The Professional Geographer, 44(4), 377-392.

Masa'deh, R. (2016). The role of knowledge management infrastructure in enhancing job satisfaction at Aqaba five star hotels in Jordan. Communications and Network, 8(4), 219-240.

McKercher, B. (1993). Some fundamental truths about tourism: Understanding tourism's social and environmental impacts. Journal of Sustainable Tourism, 1(1), 6-16.

Milman, A., \& Pizam, A. (1988). Social impacts of tourism on central Florida. Annals of Tourism Research, 15(2), 191-204.

$\begin{array}{llllll}\text { Ministry of } & \text { Tourism } \quad \& \quad \text { Antiquities } & \text { (2017). } & \text { Retrieved }\end{array}$ http://www.mota.gov.jo/Contents/Satistical_2ndAr.aspx

Neveu, N. (2010). Islamic tourism as an ideological construction: A Jordan study case. Journal of Tourism and Cultural Change, 8(4), 327-337.

Pillinger, J. (2016). Feminising the market: Women's pay and employment in the Europeancommunity. Springer.

Pizam, A. (1978). Tourism's impacts: The social costs to the destination community as perceived by its residents. Journal of Travel Research, 16(4), 8-12.

Roy, M. J., Sato, K., \& Calò, F. (2015). Further limits to institutional isomorphism? Introducing the 'neo-contingency approach' to the field of community-led social ventures. VOLUNTAS: International Journal of Voluntary and Nonprofit Organizations, 26(6), 2536-2553.

Rudež, H. N., \& Mihalič, T. (2007). Intellectual capital in the hotel industry: A case study from Slovenia. International Journal of Hospitality Management, 26(1), 188-199.

Rutherford, D. G., \& O’Fallon, M. J. (2007). Hotel management and operations. John Wiley \& Sons.

Sautter, E. T., \& Leisen, B. (1999). Managing stakeholders a tourism planning model. Annals of Tourism Research, 26(2), 312-328.

Shackley, M. (1996). Community impact of the camel safari industry in Jaisalmar, Rajasthan. Tourism Management, 17(3), 213-218.

Shannak, R., \& Obeidat, B. (2012). Culture and the implementation process of strategic decisions in Jordan. Journal of Management Research, 4(4), 257-281.

Sharpley, R., \& Forster, G. (2003). The implications of hotel employee attitudes for the development of quality tourism: The case of Cyprus. Tourism Management, 24(6), 687-697.

Shryock, A. (2004). The new Jordanian hospitality: House, host, and guest in the culture of public display. Comparative Studies in Society and History, 46(1), 35-62.

Shunnaq, M., Schwab, W. A., \& Reid, M. F. (2008). Community development using a sustainable tourism 
strategy: A case study of the Jordan river valley tourist way. International Journal of Tourism Study, 10(1), $1-14$.

Sirgy, M. J., Widgery, R. N., Lee, D. J., \& Grace, B. Y. (2010). Developing a measure of community well-being based on perceptions of impact in various life domains. Social Indicators Research, 96(2), 295-311.

Taylor, M. (2011). Building social capital through rhetoric and public relations. Management Communication Quarterly, 25(3), 436-454.

Thomson, A. M., Smith-Tolken, A. R., Naidoo, A. V., \& Bringle, R. G. (2011). Service learning and community engagement: A comparison of three national contexts. VOLUNTAS: International Journal of Voluntary and Nonprofit Organizations, 22(2), 214-237.

Tosun, C. (2002). Host perceptions of impacts: A comparative tourism study. Annals of Tourism Research, 29(1), 231-253.

Walpole, M. J., \& Goodwin, H. J. (2000). Local economic impacts of dragon tourism in Indonesia. Annals of Tourism Research, 27(3), 559-576.

Wong, S. C., \& Ko, A. (2009). Exploratory study of understanding hotel employees' perception on work-life balance issues. International Journal of Hospitality Management, 28(2), 195-203.

Wood, E. H. (2008). An impact evaluation framework: Local government community festivals. Event Management, 12(3-4), 171-185. https://doi.org/10.3727/152599509789659768

\section{Copyrights}

Copyright for this article is retained by the author(s), with first publication rights granted to the journal.

This is an open-access article distributed under the terms and conditions of the Creative Commons Attribution license (http://creativecommons.org/licenses/by/4.0/). 